\title{
RECRUITMENT IN THE ENGINEERING INDUSTRY IN BRITAIN
}

$\mathrm{A}$ JOINT discussion between Section G (Engineering) and Section I (Education) at the British Association meeting at Oxford on September 7 was opened by Dr. Willis Jackson, director of research and education, Metropolitan-Vickers Electrical Co., Ltd., who emphasized the great gap between the numbers and quality of recruits needed by the engineering industry and the boys actually coming from the schools. He stressed the importance of continued education, general as well as technical, and of systematic practical training. $\mathrm{He}$ believes, however, that there is a fundamental change in attitude on this question based on the recognition of its national importance and arising from the increasing number of men in high executive positions who themselves have had a sound engineering education. The engineering industry, Dr. Willis Jackson said, needs recruits at three levels-professional engineers, technicians, and craftsmen. These sometimes overlap; but each has an essential place in the industry, and he believes that it is the facilities for training technicians which are the least satisfactory, partly because the need for training them systematically has not been clearly appreciated. More deliberately organized courses of practical training and technical study are needed here; but Dr. Jackson stressed the need for more flexibility in training all types of recruits, and also the importance of corporate life during industrial training and the value of the activities of apprentice associations.

Dr. Jackson was particularly concerned with the recruitment of professional engineers. The number of corporate members admitted to the Institutions of Civil, Mechanical and Electrical Engineers has increased from 2,741 in 1951 to 3,310 in 1953 , of whom 1,444 possessed a university degree, as compared with 1,215 in 1951. Nevertheless, while the facilities for engineering students at the universities have increased, they are not being used: three hundred first-year places in university engineering schools were unfilled this year and two hundred more will be available in the next three years. More disturbing still, in one university thirty per cent of those accepted failed to pass their first-year examination. Dr. Jackson wondered whether we are trying to draw into the university engineering schools boys who would be better served by entering industry as student apprentices. He also thought that there is a need for better means of informing boys and parents as to the nature and prospects of engineering as a career.

Mr. Donald Lindsay, headmaster of Malvern College, who followed, flatly challenged the assumption that it is the business of the grammar school to produce engineers or any other particularly qualified group. The percentage of able boys is limited to about ten per cent of the school population, and this proportion has to supply all the professions with their best men. In his opinion, the school should be neutral, and should not attempt to influence recruitment for any particular profession. Nevertheless, Mr. Lindsay believes that the engineering profession could do more to attract not the outstandingly able boy, who usually knows his own mind, but the lessable boy, who, like his parents, often has the vaguest ideas of what it means to become an engineer. $\mathrm{He}$ suggested that the engineering industries could follow the example of the Armed Services in preparing a single-page document explaining clearly methods of entry and age and educational requirements for their various branches. Mr. Lindsay is also concerned at the possible effect on the prospects of the less-able boys of the new certificate examinations at ordinary level, and still more at the consequences for such boys of the shortage of science teachers and especially the decline in quality of science teachers.

Mr. H. A. Warren, principal of East London Technical College, outlining the contribution of the technical colleges to recruitment and training for the engineering industries, pointed out that grammar schools provided 45 per cent of the technical college students who obtained their Higher National Certificate in 1953. He said that the quality of the work of the technical colleges reaches as high a standard as the grade of student entry permits. The standard of teaching is good, the scale of equipment excellent and also the co-operation from industry, and so far as the student is characterized by a narrowness of outlook, it should be corrected by the philosophy and outlook of this age. Technology, he urged, should be restored to the service of the liberal ends of human life and character ; and, referring to the proposals for a new national award in technology, Mr. Warren said that not only has any new award to prove its worth, but also it is essential for it to encourage breadth of outlook and height of aspiration, thus bearing witness to those social, cultural and philosophical qualities which were the original characteristics of a university degree.

\section{ATTITUDES TO WORK}

TN an address to the Industrial Section of the British I Psychological Society*, Prof. L. S. Hearnshaw stated that as soon as psychologists have become convinced that values have a place in the world of fact and not only in the heads of philosophers, and that they are capable of being investigated by empirical means, the main resistances to their study will have been overcome, and one of the chief regulators of human behaviour brought within the framework of psychological study.

The growing number of attitude surveys that have been carried out among industrial workers since the War is a recognition that this area of psychology is industrially important. For the study of attitudes merges necessarily into the study of values. The difficulties confronting the psychologist in these studies are formidable and even discouraging.

The most suggestive observations on attitudes to work have come not from industrial psychologistswith the exception possibly of Mace, who is $a_{0}$ man of many parts - but from an economist, like Zweig, a historian, like Carr, a philosopher, like Salmon, or from the mainly amateur members of productivity teams.

On the whole, the studies carried out by industrial psychologists themselves in the field of industrial attitudes have been restricted in their frames of

\footnotetext{
* Occupational Psychology, 28, No. 3 (July 1954).
} 